\title{
AN ANALYSIS OF CLASSROOM MANAGEMENT DIFFICULTIES IN THEMATIC LEARNING IN SD N 2 KUTOSARI
}

\section{Ana Nur Fajriyati, Mutiara Anggun Puspitasari}

Universitas Sebelas Maret

ananurfajriyati1@gmail.com

\section{Article History}

accepted 30/09/2018

approved $12 / 10 / 2018$

published 30/10/2018

\section{Keywords}

Curriculum 2013,

Classroom Management, Thematic Learning

\begin{abstract}
Curriculum 2013 has started to be implemented in schools, including in SD N 2 Kutosari. One of its realizations is the thematic learning for grade 1, 2, 4, and 5. The implementation needs a good classroom management in order to achieve maximum learning objectives. However, in the actual act, there are still teachers who have difficulties in managing the classroom for the thematic learning. The purpose of this research was to describe problems in the classroom management for the thematic learning in SD N 2 Kutosari. The approach used in this research was qualitative with descriptive analysis. The data were collected through observation, documentation, and interview to the teachers. Result showed that there are problems, such as (1) Students feltbored easily to the learning subject (2) Students were busy talking with their friends (3) Students were busy to get attention from the teachers and the other students (4) The number of students in class exceeded the ideal number (5) Students tended to choose friends in group discussion (6) Less interesting subject (7) A static classroom setting.
\end{abstract}

Social, Humanities, and Education Studies (SHEs): Conference Series https://jurnal.uns.ac.id/shes 


\section{PENDAHULUAN}

Sistem pendidikan di Indonesia hingga saat ini masih dihadapkan dengan sejumlah permasalahan. Salah satunya yaitu rendahnya mutu pendidikan di Indonesia, Padahal di era global ini dibutuhkan sistem pendidikan yang baik agar menghasilkan lulusan yang berkualitas dan kompeten. Kunandar menjelaskan bahwa rendahnya kualitas pendidikan di Indonesia dapat dilihat dari beberapa faktor antara lain: pertama, lulusan dari sekolah atau perguruan tinggi yang belum siap memasuki dunia kerja karena minimnya kompetensi yang dimiliki. Kedua, peringkat Human Development Index (HDI) Indonesia masih rendah, Ketiga, laporan International Educational Achievement bahwa kemampuan membaca siswa Sekolah Dasar (SD) Indonesia berada pada urutan 38 dari 39 negara yang disurvey (Janawi, 2012:1-3).

Untuk mengatasi permasalahan tersebut pemerintah berupaya memperbaiki sistem pendidikan yang ada di Indonesia. Salah satu cara yang dilakukan yaitu dengan melakukan penyempurnaan kurikulum. Penyempurnaan kurikulum ini sudah terjadi dalam beberapa tahun terakhir. Dimulai pada tahun 2004 sistem pendidikan di Indonesia menggunakan Kurikulum Berbasis Kompetensi (KBK), lalu pada tahun 2006 diganti dengan Kurikulum Tingkat Satuan Pendidikan (KTSP), dan yang terbaru pada tahun 2013 pemerintah menerapkan Kurikulum 2013. Implementasi kurikulum 2013 di sekolah mulai dilaksanakan pada tahun ajaran 2013/2014. tetapi pada pelaksanaannya banyak sekolah yang mengalami kesulitan sehingga sekolah kembali ke kurikulum KTSP. Kurikulum 2013 kembali diberlakukan secara nasional pada tahun ajaran 2016/2017 setelah dilakukan revisi.

Salah satu sekolah dasar yang sudah menerapkan kurikulum 2013 di Kabupaten Kebumen yaitu SD Negeri 2 Kutosari. Pada tahun ajaran 2018/2019 sudah ada 4 kelas yang menggunakan kurikulum 2013 yaitu kelas 1,2,4, dan 5 . Sedangkan untuk kelas 3 dan 6 masih menggunakan Kurikulum Tingkat Satuan Pendidikan (KTSP). Landasan yuridis pelaksanaan kurikulum 2013 yaitu Permendikbud Nomor 56 tahun 2013 tentang Standar Proses Pendidikan Dasar dan Menengah menyebutkan bahwa "Sesuai dengan Standar Kompetensi Lulusan dan Standar Isi, maka prinsip pembelajaran yang digunakan dari pembelajaran parsial menuju pembelajaran terpadu". Hal ini kemudian dipertegas dalam Permendikbud Nomor 67 Tahun 2013 tentang Kerangka Dasar dan Struktur Kurikulum SD/MI menyebutkan bahwa "Pelaksanaan Kurikulum 2013 pada SD/MI dilakukan melalui pembelajaran dengan pendekatan tematik-terpadu dari kelas I sampai kelas Vl". Akbar, dkk (2016:17) menjelaskan bahwa pembelajaran tematik adalah pendekatan pembelajaran yang mengintegrasikan berbagai kompetensi dari berbagai mata pelajaran ke dalam tema dengan proses pembelajaran yang bermakna disesuaikan dengan perkembangan siswa.

Menurut Widyaningrum (2012:15) pengintegrasiaan beberapa mata pelajaran dalam satu tema akan memberikan keuntungan diantaranya: (1) siswa mudah memusatkan perhatian pada suatu tema tertentu; (2) siswa mampu mempelajari pengetahuan dan mengembangkan berbagai kompetensi dasar antar mata pelajaran dalam tema yang sama; (3) pemahaman terhadap materi pelajaran lebih mendalam; (4) kompetensi dasar dapat dikembangkan lebih baik dengan mengaitkan mata pelajaran lain dengan pengalaman pribadi siswa; (5) siswa mampu merasakan manfaat dan makna belajar karena materi disajikan dalam konteks tema yang jelas; (6) siswa mampu bergairah belajar karena dapat berkomunikasi dalam situasi nyata; (7) guru dapat menghemat waktu karena mata pelajaran yang disajikan secara tematik dapat dipersiapkan sekaligus.

Pendekatan tematik tepat jika diterapkan di sekolah dasar karena sesuai dengan teori perkembangan kognitif, bahwa siswa SD masih belum bisa berpikir secara terpisah-pisah, tetapi mereka berpikir tentang suatu objek sebagai sesuatu yang konkret. Prinsip-prinsip dari pembelajaran tematik yaitu: (1) memiliki satu tema aktual yang dekat dengan dunia siswa dan ada dalam kehidupan sehari-hari; (2) memilih 
materi dari beberapa muatan yang saling terkait sehingga dapat mengungkapkan tema secara bermakna; (3) tidak bertentangan dengan kurikulum yang berlaku; (4) materi pembelajaran dipadukan dalam satu tema; (5) materi yang dipadukan tidak dipaksakan. (Akbar, dkk., 2016:18-19). Menurut Isbadrianingtyas, dkk (2016:901) pada pembelajaran tematik, ada beberapa komponen yang berkaitan dalam pelaksanaannya. Komponen tersebut diantaranya peran guru dan siswa, strategi pembelajaran tematik dan pengelolaan kelas.

Menurut Djamarah dan Aswan (2013:173) pengelolaan kelas adalah keterampilan guru untuk menciptakan dan memelihara kondisi belajar yang optimal dan mengembalikannya bila terjadi gangguan dalam proses belajar mengajar. Jasmina Delceva (2014) menyebutkan bahwa "The management of classroom is a process that icludes different activities done by teacher and student alike, but also teaching subjects that have to be aligned with both the needs and abilities of the students, and the previously established teaching goals. Menurut Sunaryo dan Nyoman perlunya kemampuan mengelola kelas yang dimiliki oleh seorang guru karena pembelajaran adalah proses membantu siswa belajar, yang ditandai dengan perubahan perilaku baik dalam aspek kognitif maupun psikomotorik ( Sunhaji 2014:35 ). Dengan kemampuan mengelola kelas yang baik maka tujuan pembelajaran dapat tercapai optimal. Zahroh, L (2015:176) menjelaskan alasan guru harus melakukan pengelolaan kelas yaitu: (1) mengelola kelas merupakan faktor yang dapat menciptakan dan mempertahankan suasana serta kondisi kelas agar selalu tampak efektif; (2) Dengan mengelola kelas yang baik, maka interaksi antara guru dengan siswadapat terjalin dengan baik; (3) Kelas juga menjadi tempat dimana kurikulum pendidikan dengan segala komponennya, materi dengan sumber pelajarannya, serta segala pokok bahasan mengenai materi itu diajaran dan ditelaah ulang di dalam kelas, dan; (4) Karena dari hari ke hari, bahkan dari waktu ke waktu, tingkah laku siswaselalu berubah-ubah sesuai dengan pertambahan usia, perkembangan karakter, dan meluasnya pergaulan mereka.

Meskipun guru di SD Negeri 2 Kutosari sudah melakukan pengelolaan kelas dalam pembelajaran tematik, belum dipastikan sepenuhnya bahwa kelas akan kondusif. Hal itu disebabkan karena kepribadian berbeda-beda antar siswa yang satu dengan siswa yang lain,serta kondisi lingkungan siswa yang memengaruhi konsentrasi siswa. Kendala dalam pengelolaan kelas dapat berasal dari faktor siswa dan guru, serta dari faktor fisik. Kendala yang berasal dari guru dan siswa dapat disebabkan karena kegiatan belajar mengajar yang monoton, kurangnya kesadaran siswa dalam memenuhi tugasnya sebagai anggota kelas, serta interaksi antar anggota kelas yang kurang baik. Kendala yang berasal faktor fisik yaitu kondisi ruang kelas yang tidak sebanding dengan jumlah siswa serta setting kelas yang monoton. Berdasarkan paparan di atas, peneliti tertarik untuk melakukan penelitian yang berjudul "Analisis Kesulitan Pengelolaan Kelas Dalam Pembelajaran Tematik Di SD Negeri 2 Kutosari”.

Berdasarkan permasalahan tersebut peneliti ingin mengajukan permasalahan sebagai berikut: (1) Faktor-faktor yang berpengaruh terhadap pengelolaan kelas (2) Permasalah dalam pengelolaan kelas pada pembelajaran tematik. (3) Solusi pengelolaan kelas yang efektif. Tujuan penelitian ini untuk: (1) Mendeksripsikan faktorfaktor yang berpengaruh terhadap pengelolaan kelas (2) Mendeskripsikan permasalahan dalam pengelolaan kelas pada pembelajaran tematik (3) Menguraikan dampak pengelolaan kelas (4) Menjelaskan solusi pengelolaan kelas yang efektif.

\section{METODE PENELITIAN}

Pendekatan yang digunakan dalam penelitian ini adalah pendekatan kualitatif. Dalam penelitian ini peneliti berusaha memperoleh gambaran yang menyeluruh mengenai permasalahan yang diteliti. Data-data yang diperoleh dalam penelitian ini diperoleh peneliti melalui wawacara dengan guru kelas di SD Negeri 2 Kutosari, serta melalui 
observasi guru kelas selama proses pembelajaran tematik. Alat pengumpulan data yang digunakan dalam penelitian ini berupa pedoman wawancara, serta lembar observasi. Data yang sudah diperoleh akan dianalisis dan dipaparkan secara deskriptif.

\section{HASIL DAN PEMBAHASAN}

Keberhasilan kegiatan belajar mengajar tidak semata-mata ditentukan oleh kemampuan guru dalam menguasai materi pelajaran. Namun juga bagaimana guru mampu menciptakan dan mempertahankan kondisi kelas agar siswa mampu mengikuti pebelajaran secara optimal. Guru sebagai seorang pendidik dituntut untuk memiliki berbagai keterampilan. Salah satunya adalah keterampilan mengelola kelas.

Pada segmen pembahasan, ada tiga pokok persoalan yang dibahas yaitu: (1) faktor-faktor yang berpengaruh terhadap pengelolaan kelas (2) permasalahan dalam pengelolaan kelas, dan (3) solusi pengelolaan kelas yang efektif.

\section{a. Faktor-faktor yang berpengaruh terhadap pengelolaan kelas}

Menurut Suharsimi pengelolaan kelas terdiri dari dua segi, yaitu pengelolaan kelas yang menyangkut siswa, dan pengelolaan fisik (sarana dan prasarana pembelajaran). Selanjutnya dikatakan bahwa membuka jendela agar udara segar masuk atau agar membuat ruangan menjadi lebih terang, menyalakan lampu listrik, menggeser papan tulis, mengatur meja, merupakan kegiatan pengelolaan fisik (Djamarah dan Aswan Zain, 2013: 117).

Dalam pelaksanaan pengelolaan kelas akan ditemui bermacam-macam faktor pendukung dan penghambat. Menurut Setya Budi, dkk (2018:29) Faktor pendukung dalam pengelolaan kelas meliputi keterampilan guru dalam pengelolaan kelas, manajemen sekolah, partisipasi siswa dalam kelas. Komponen keterampilan pengelolaan kelas terbagi menjadi dua bagian, yaitu keterampilan yang berhubungan dengan penciptaan dan pemeliharaan kondisi belajar yang optimal dan keterampilan yang berhubungan dengan pengembangan kondisi belajar yang optimal.

Manajemen sekolah adalah kemampuan pihak sekolah dalam memfasilitasi sarana yang dapat mendukung terciptanya kondisi pembelajaran yang menguntungkan. Partisipasi siswa merupakan keinginan siswa untuk tetap mengikuti alur permainan atau proses pembelajaran yang telah disepakati bersama.

Berdasarkan hasil observasi dan wawancara yang telah dilakukan, fakor pendukung dalam pengelolaan kelas pada pembelajaran tematik di SD $\mathrm{N} 2$ Kutosari yaitu guru sudah memiliki keterampilan mengajar yang baik dan guru mampu mengubah suasana pembelajaran dikelas yang kurang kondusif karena terdapat ulah seorang siswa atau sekelompok siswa menjadi suasana kelas yang lebih kondusif. Menejemen di SD N 2 Kutosari sangat baik, semua kegiatan terjadwal dan terencana dengan baik. Sarana dan prasarana yang dimiliki sekolah sudah cukup lengkap untuk mendukung kegiatan belajar mengajar yaitu 3 dari 6 kelas sudah terpasang LCD, untuk kelas yang belum terpasang LCD permane pihak sekolah menyediakan LCD portable serta menyediakan speaker untuk menyempurnakan pembelajaran. Partisipasi siswa dalam pembelajaran aktif dan proaktif. Siswa dalam setiap pembelajaran sangat antusias terlihat dari banyak pertanyaan yang dilontarkan ke guru ketika proses pembelajaran serta siswa berebut untuk menyampaikan pendapatnya.

Sementara itu faktor penghambat dalam pengelolaan kelas menurut Setya Budi (2018:30) bisa datang dari faktor guru, faktor siswa, dan faktor fasilitas. Faktor guru dapat berupa (a) tipe kepemimpinan guru, guru yang kurang demokratis atau otoriter bisa menumbuhkan sikap atau tingkah laku yang kurang kondusif dari siswa. (b) kepribadian guru, guru dituntut memiliki kepribadian yang kuat dan kepercayaan diri yang tinggi. guru yang memiliki 
kepribadian yang kuat ia senantiasa bersikap sabar, hangat, adit, objektif, dan fleksibel dalam menanggapi masalah yang dihadapi siswa. (c) metode mangajar guru. Guru yang kurang memperhatikan dalam memilih strategi yang tepat dan menarik akan membuat siswa menjadi mudah bosan dan malas sehingga mereka banyak melanggar peraturan sekolah. (d) pemahaman guru tentang psikologi perkembangan siswa. Terbatasnya kesempatan guru untuk memahami tingkah laku siswa dan latar belakangnya disebabkan karena kurangnya usaha guru untuk memahami siswa dan latar belakangnya.

Sementara itu untuk faktor yang berasal dari siswa yaitu kekurangsadaran siswa dalam memenuhi tugas dan haknya sebagai anggota suatu kelas atau satu sekolah dapat merupakan faktor utama penyebab masalah pengelolaan kelas. Faktor fasilitas meliputi (1) jumlah siswadi dalam kelas. Jumlah siswa dalam satu kelas di SD yang mencapai rata-rata 30-40 orang siswa merupakan masalah tersendiri dalam pengelolaan kelas. (2) Besar ruangan kelas. Ruang kelas yang kecil dibandingkan jumlah dan kebutuhan siswa untuk bergerak dalam kelas merupakan hambatan lain bagi pengelolaan. Demikian pula kurangnya ruangan khusus yang dibutuhkan seperti laboratorium komputer, ruang kesenian, aula, dan sebagainya yang memerlukan penangan tersendiri. Ketersediaan alat dan jumlah buku yang kurang dengan jumlah siswayang membutuhkannya.

Di SD N 2 Kutosari yang menjadi faktor penghambat adalah jumlah siswa di kelas 4 dan 5 lebih dari 30 siswa sehingga guru membutuhkan usaha lebih untuk mengondisikan siswa dengan karakteristik yang berbeda-beda. Ruangan kelas 5 pencahayaan kurang baik dan kurang luas untuk jumlah siswa yang ada. Selain itu jumlah ruangan khusus seperti laboratorium komputer, aula, dan sebagainya masih kurang karena terbatasnya luas lahan sekolah.

\section{b. Permasalahan dalam pengelolaan kelas pada pembelajaran tematik}

Berdasarkan hasil observasi dan wawancara yang telah dilakukan dengan guru kelas 1, 2, 4, dan 5. Permasalahan yang terjadi dalam pengelolaan kelas pada pembelajaran tematik di SD N 2 Kutosari yaitu sebagai berikut (1) Perilaku individu siswa, berupa bertingkah menarik perhatian orang lain, siswa bertingkah menguasai orang lain, perilaku siswa untuk membalas dendam, dan peragaan ketidakmampuan yaitu siswa bersiap apatis terhadap pekerjaan yang diberikan guru karena ia yakin akan menemui kegagalan.(2) Perilaku siswaketika berkempok meliputi siswa yang pilih-pilih teman dalam berkelompok, kelas mereaksi negatif terhadap salah seorang anggota contohnya mengolok-olok teman, mengucilkan, bermusuhan, ribut, merendahkan kelompok bodoh.

\section{c. Solusi pengelolaan kelas yang efektif}

Agar pengelolaan kelas menjadi efektif beberapa prinsip yang harus diketahui dan digunakan oleh guru dalam mengelola kelas. prinsip tersebut yaitu (1) Kehangatan dan keantusiasan. Kehangatan dan keantusiasan guru dapat memudahkan terciptanya suasanya kelas yang menyenangkan yang merupakan salah satu syarat membuat kegiatan belajar mengajar menjadi lebih maksimal. (2) Tantangan. Pengunaan kosa kata, tindakan, bahan dan media pembelajaran yang menantang akan memantik gairah dan antusias siswa untuk belajar sehingga mengurangi kemungkinan munculnya perilaku yang menyimpang dari siswa. (3) Bervariasi. Penggunaan alat atau media, gaya dan interaksi belajar mengajar yang bervariasi merupakan kunci tercapainya pembelajaran yang menyenangkan agar siswa tidak mengalami kebosanan. (4) Keluwesan. Keluwesan tingkah laku guru untuk mengubah strategi 
mengajarnya dapat mencegah kemungkinan munculnya gangguan siswaserta menciptakan iklim belajar-mengajar yang efektif. (5) Penekanan pada hal-hal yang positif. Pada dasarnya di dalam mengajar dan mendidik, guru harus memberikan penekanan pada hal-hal positif dan menghindari pemusatan perhatian siswapada hal-hal yang negarif. (6) Penanaman disiplin diri. pengembangan disiplin diri sendiri oleh siswamerupakan tujuan akhir dari pengelolaan kelas. oleh karena itu guru harus selalu mendorong siswaagar selalu disiplin diri sendiri, dan guru sebaiknya menjadi contoh atau teladan tentang pengendalian diri dan pelaksanaan tanggung jawab (Djamarah dan Aswan Zain, 2013: 185).

\section{SIMPULAN}

Dalam pembahasan di atas, dapat disimpulkan bahwa kesulitan pengelolaan kelas dalam pembelajaran tematik di SD N 2 Kutosari terdiri dari pengelolaan fisik dan pengelolaan siswa. Pengelolaan fisik terkait sarana dan prasarana sementara pengelolaan siswa berkaitan dengan perilaku siswa. Faktor-faktor yang berpengaruh dalam pengelolaan kelas terdiri dari faktor pendukung yaitu keterampilan guru, menajemen sekolah, partisipasi siswa. Sementara itu faktor penghambat terdiri dari faktor siswa dan faktor fasilitas. Permasalahan dalam pengelolaan kelas yang muncul yaitu perilaku individu siswa dan perilaku siswa dalam kelompok. Solusi untuk mengatasi permasalahan yang muncul dalam pengelolaan kelas yang tepat yaitu dengan memperhatikan prinsip-prinsip pengelolaan kelas berupa hangat dan antusias, tantangan, bervariasi, keluwesan, penekanan pada hal-hal positif, dan penanaman disiplin diri.

Implikasi dari penelitian ini guru mampu mengetahui permasalahan yang dialami dalam pembelajaran tematik kemudian mampu menemukan solusi yang tepat untuk mengatasi permasalahan yang terjadi di kelas. Penelitian ini dapat digunakan sebagai referensi untuk menambah wawasan guru kelas untuk menganalisis masalah yang dialami di kelas sehingga mampu meningkatkan kualitas pengelolaan pembelajaran agar tujuan pembelajaran dapat tercapai secara optimal.

\section{DAFTAR PUSTAKA}

Akbar, dkk. (2016). Implementasi Pebelajaran Tematik di Sekolah Dasar. Bandung: PT Remaja Rosdakarya

Budi, Setyo. (2018). Kiat Jitu Mengelola Kelas. Sukoharjo: CV. Farishma Indonesia

Delceva, J. (2014). Classroom Management. International Journal of Cognitive Research in Science, Engineering and Education. 2 (1), 51-55.

Djamarah, S.B., dan Aswan Zain. (2013). Strategi Belajar Megajar. Jakarta; Rineka Cipta

Isbadrianingtyas, N., dkk. (2016). Pengelolaan Kelas dalam Pembelajaran Tematik di Sekolah Dasar. Jurnal Pendidikan: Teori, Penelitian, dan Pengembangan. 1 (5), 901-904

Janawi. (2012). Kompetensi Guru Citra Guru Profesional. Bandung:Alfabeta

Sunhaji. (2014). Konsep Manajemen Kelas dan Implikasinya dalam Pembelajaran. Jurnal Kependidikan, 2 (2), 35.

Widyaningrum, R. (2012). Model Pembelajaran Tematik di SD/MI. Jurnal Cendekia, 10 (1), 15.

Zahroh, L., (2015). Pendekatan dalam Pengelolaan Kelas. Jurnal Tasyri', 22 (2), 175189. 